\title{
The study of bioenergy with molasses raw materials: analysis of potential and problems in its development in East Java, Indonesia
}

\author{
Adang Agustian ${ }^{1,}$, Ening Ariningsih ${ }^{1}$, Endro Gunawan ${ }^{1}$, and Kurnia Suci Indraningsih ${ }^{1}$ \\ ${ }^{1}$ Indonesian Center for Agricultural Socio Economic and Policy Studies, Jln. Tentara Pelajar 3B, \\ Bogor, Indonesia.
}

\begin{abstract}
The Indonesian government is gradually reducing its dependence on petroleum fuels by mixing it with biofuels. One of the biofuels used is bioethanol made from molasses. This study aims to analyze the potential for sugarcane development at the farm level, identify bioenergy problems, and provide bioenergy development recommendations based on molasses. The research was conducted in East Java Province in 2016, with updated data in 2019. The analytical methods used were quantitative and qualitative. The results of the research are as follows. In 2019, the potential of molasses produced reached 260.06 thousand tons in East Java Province. However, there are some technical and socio-economic problems in developing biofuels from molasses, including the low yield of sugar, limited processing of molasses into bioethanol, lack of bioethanol marketing guarantee, and lack of synergy in bioethanol policy development. Some policy recommendations proposed to support the sustainability of bioethanol production in the future are policy supports for increasing sugarcane farming, capital support for bioethanol producers, guarantee in the bioethanol marketing, and synergies in developing bioenergy policies.
\end{abstract}

\section{Introduction}

Currently, the Government of Indonesia has made a policy that aims to reduce petroleum use by 5-20 percent by 2025 . Through this policy, it is expected that biofuel (BBN) can gradually replace fuel oil (BBM). The implementation of biofuel (bioethanol) mixed with $\mathrm{BBM}$ has been carried out, using sugarcane drop (molasses) as a raw material for bioethanol. Molasses is a by-product of the sugarcane industry, which still contains high enough sugar $[1,2,3]$.

Several studies showed that bioethanol production efficiency could be obtained by selecting types of microorganisms, raw materials, and control of the fermentation process $[4,5]$. The use of bioethanol as an alternative fuel provides many benefits for the people of Indonesia. This is in line with the support of the abundance of biological resources in

\footnotetext{
${ }^{*}$ Corresponding author: aagustian08@gmail.com
} 
Indonesia as raw materials. This type of renewable energy has energy resources that naturally will not run out and can be sustainable if appropriately managed [6].

Sugarcane (Saccharum officinarum), as a raw material for the sugar industry, has an essential role in the Indonesian and several other countries' economies. Molasses, a byproduct that resulted from making cane sugar that has been processed into ethanol, will have a high export value $[7,8]$. Bioethanol is one of the potential alternative energy sources to be developed and can be a foreign exchange source. Besides, bioethanol fuel is considered more environmentally friendly because plants will absorb the $\mathrm{CO}_{2}$ produced by engine waste $[9,10,11,12,13,14]$.

In anticipating an energy crisis in the future, developed countries have directed strategic energy policies by shifting the use of fossil energy to renewable energy, including bioethanol. Therefore, support from the technical aspect related to the expansion of sugarcane planting areas (extensification) is one option that can be taken by the government. This effort aims to increase national sugar production (as food) and support bioethanol production.

Furthermore [15] in 2012 revealed the development of New and Renewable Energy (EBT) to achieve the target by 2025. For this development, two development stages are needed: the operational action stage and the institutional reform stage. These stages are intended to (a) increase the effectiveness of the national management system by encouraging resource management according to the constitution; (b) fix various regulations that have the potential to overlap; (c) build harmony between the central and regional governments related to the development of renewable energy including bioenergy; and (d) improve performance and institutional capacity related to the development of EBT, especially bioenergy. In line with this, the development of networks between R \& D institutions in the EBT field has been carried out by forming a network or communication forum, including the Indonesian Biodiesel Forum, Bioenergy Association, and the Indonesian Renewable Energy Society.

As has been described above, research on bioethanol made from molasses has been widely carried out. However, there is still no comprehensive study on the potential of developing bioethanol made from molasses, its technical and socio-economic constraints, and its feasibility analysis, especially in East Java Province. Apart from that, various information was also collected at the central, provincial, and research location levels. Information collected from policymakers was related to energy, including the Ministry of Energy and Mineral Resources (EMR), the EMR Office, Plantation Service Office, the industry processing molasses into bioethanol, and sugarcane farmers. This is a novelty aspect of this study.

Based on the description above, this study aims to analyze the potential of developing bioethanol made from molasses, identify problems in its development, and provide alternative suggestions for the development of bioethanol made from molasses as raw material.

\section{Methodology}

\subsection{Theoretical framework}

Food, water, energy, and metals are the drivers of industrial, economic, and social growth. As the world's population increases and the louder voices demand a higher standard of living, there is competition for access to resources given that energy is one of the basic needs to sustain human life. This competition will have implications for the intensity of the power struggle between countries over resources. Therefore, increasing the diversification 
of energy sources is an important part of meeting human needs. One potential energy source to be developed is vegetable raw materials $(\mathrm{BBN})$ from the agricultural sector [16, 17].

There are several reasons why biofuel development is potential to be developed in Indonesia: (1) The availability of various biofuel raw materials and land suitable for biofuel raw material development. (2) The biofuel process technology has been controlled by domestic human resources (engineering, research, and development). (3) The biofuel industry involves the community's participation, including farmers, so that it will increase farmers' income and overcome the high unemployment rate (up to 10 million open unemployed people) and the poverty rate (39.1 million people). (4) The development of biofuel is an opportunity for regional governments to increase economic development and export biofuel. The existence of greenhouse gases (GHG) is the cause of global warming. Therefore, clean energy biofuel is one way of reducing $\mathrm{CO} 2$ emissions from the energy sector. In line with this, the government also launched the Indonesia Green Energy Action Plan. The development of green energy or energy made from vegetable raw materials has important aspects believed to boost the national economy [10, 30, 31].

The current use of bioenergy in the field includes PTPN XII East Java, which uses biodiesel from Jatropha to operate agricultural equipment (machines) and electric generators. Almost all diesel-fueled vehicles already use biodiesel after the engine is equipped with a preheater [7]. Meanwhile, bioenergy development in the field still faces obstacles in biofuel development [10]. These constraints include (a) the short-term biofuel development target is not achieved due to market factors, weak government policies, and lack of coordination between related institutions and actors; (b) policies in the energy, forestry, and plantation sectors are sufficient to support efforts to accelerate the procurement and use of biofuel but contain weaknesses to mitigate negative impacts; (c) there is a positive impact of oil palm development on the central and regional economies and communities, especially oil palm smallholders

In accordance with the concept of Integrated Food Energy Systems (IFES), agricultural development is an ingenious solution in Integrated Agricultural Development. The concept of integrated development aims to simultaneously address problems in producing food and energy as a way to achieve a sustainable energy component of plant intensification through an ecosystem approach $[18,32]$.

Some other studies in several countries can provide lessons for bioethanol development policies in Indonesia. The success of bioethanol development made from sugarcane in Brazil is at least supported by several factors such as (1) the availability of adequate raw materials for bioethanol raw materials due to the availability of sufficient land for planting sugar cane; (2) the existence of production technology that processes sugarcane into adequate ethanol; and (3) domestic consumption of bioethanol is particularly supportive of sustainable motor vehicle fuel [19, 31]. Bioenergy development in China has also had positive results in terms of environmental friendliness, energy efficiency, and added value creation for producers in line with the increasing demand for bioenergy products (bioethanol and biodiesel) in the domestic and foreign markets [20].

Ethanol production in Brazil increased from 0.6 billion liters in 1975/1976 to 27.6 billion liters in 2009/2010. Although production costs in 1975/1976 were three times higher than the price of gasoline in the international market, they decreased dramatically due to technological advances and economies of scale that were competitive (without subsidies) with gasoline after 2004. This was achieved through appropriate government policies in Brazil. Policies as a strategy to reduce oil imports in the country. This is also in line with the results of a study that states that ethanol from sugar cane can substitute gasoline for about 50 percent. Ethanol is a better fuel than gasoline and is also a renewable energy that 
contributes to low greenhouse gas emissions [21]. Likewise, in Mozambique, implementing the mandate for mixing BBM with bioethanol has started in 2020 [22]. In the European Union, a direct-ethanol production process has been carried out with Beta process technology for fuel purposes to encourage the development of small and medium enterprises [23].

\subsection{Data types and data sources}

The study was carried out in 2016, with updated data for 2019, in Malang and Mojokerto Regencies, East Java Province. Data collected included primary and secondary data. Primary data were gathered from sugarcane farmers, PTPN X, the Plantation Office and the ESDM Office in East Java Province and corresponding regencies, and PT Enero. The respondents for this study included as many as 30 sugarcane farmers in each study site. Secondary data/information was collected from various agencies at the central and regional levels, including statistical data and literature related to sugarcane farming and processing sugarcane molasses into bioethanol. Primary data from farmers were gathered using a structured questionnaire. A semi-structured questionnaire was used to obtain information from the Plantation Office, PT Enero, and the Smallholder Sugarcane Farmers Cooperatives.

\subsection{Data analysis}

Data/information analysis was carried out both quantitatively and qualitatively. Analysis of the potential of sugarcane development for molasses production and identification of molasses development problems was done descriptive-qualitatively. Besides, analysis to determine the selling price of raw materials (molasses, the estimated cost of bioethanol production, and estimated price of raw material was done quantitatively.

The calculation of processing costs and raw material prices for processing per liter of bioethanol is carried out with the following formula.

$$
C_{B}=\frac{C_{1}}{R_{1} * R_{2}}+\frac{C_{2}}{R_{2}}+C_{3}
$$

where:

$\mathrm{CB}=$ cost per liter of bioethanol (IDR)

$\mathrm{C} 1=$ extraction cost

$\mathrm{R} 1=$ rendement of raw materials from sugarcane to semi-finished materials (molasses)

$\mathrm{R} 2=$ yield from semi-finished material (molasses) to bioethanol

$\mathrm{C} 2=$ other costs of processing from semi-finished materials to bioethanol products (IDR/liter)

C3 = distribution costs and others (IDR/liter of output)

The price per $\mathrm{kg}$ of raw material is calculated by formula (2).

$$
H_{B K S}=\frac{H_{S}-C_{B}}{R_{1} * R_{2}}
$$

where:

$\mathrm{HBKS}=$ raw material price $(\mathrm{IDR} / \mathrm{kg})$

$\mathrm{HS}=$ price of bioethanol without subsidies (IDR/liter)

$\mathrm{CB}=$ Cost of bioethanol (IDR/liter) 
$\mathrm{R} 1=$ Rendemen of raw materials to semi-finished materials

$\mathrm{R} 2=$ Rendemen of semi-finished materials to the final output (yield)

\section{Results and discussion}

\subsection{Potential development of sugarcane and molasses production in East Java}

Sugarcane, as one of the raw materials for bioethanol, is a plantation crop. The development of bioethanol using sugarcane as a raw material in Indonesia is quite potential, considering Indonesia is a relatively large sugarcane producer. The utilization of sugarcane in Indonesia imitates Brazil to utilize sugarcane for bioethanol as much as $80-90$ percent.

Bagasse as sugar factory waste is one of the potential lignocellulosic materials to be developed into energy sources such as bioethanol. The conversion of lignocellulosic materials into bioethanol has received important attention because bioethanol can substitute gasoline for transportation purposes. Lignocellulosic materials, including bagasse, consist of three main components: cellulose, hemicellulose, and lignin. The conversion process of lignocellulosic material into ethanol basically consists of pretreatment, hydrolysis of cellulose to sugar, fermentation of sugar to ethanol, and purification of ethanol through distillation and dehydration processes. The use of ethanol as fuel in Indonesia and the world will increase due to the depletion of petroleum reserves, the increasing trend of petroleum prices, the enactment of regulations on reducing greenhouse gas emissions, policies for eliminating methyl tertiary butyl ether (MTBE), and the tendency to shift consumption on environmentally friendly and renewable energy sources. The potential for obtaining ethanol from bagasse produced by sugar factories in Indonesia reaches $614,827 \mathrm{KL} / \mathrm{year}$. This potential can help meet the ethanol demand for fuel, estimated at around 1.10 million KL [24].

Bioethanol is a type of non-fossil fuel (biofuel) promoted by the Government through Presidential Decree Number 5/2006 and Presidential Instruction Number 1/2006. This fuel will gradually reduce the role of the premium. The Road Map of Biodiesel Development Policy [25] stated the following. (1) The mandatory target for bioethanol development in 2015 is 0.2 million KL (E2), the 2020 target is 0.8 million KL (E10), and the 2025 target is 3.45 million KL (E20). (2) The primary raw materials for the bioethanol source are sugarcane and sago. (3) The targeted land area for 2015 is 0.135 thousand ha $(0.035$ thousand ha of sugarcane area and 0.1 thousand ha of sago area); in 2020, it is 0.20 thousand ha ( 0.05 thousand ha of sugarcane area and 0.15 thousand ha of sago area); and in 2025 , it is 2.3 thousand ha $(0.575$ thousand ha of sugarcane area and 1.725 thousand ha of sago area).

Sugarcane cultivation as a raw material for bioethanol production will continue to be encouraged to produce an efficient and competitive product in the market. In the UK and the United States, making bioethanol has used the second-generation technology: processing bioethanol directly from cellulose. So far, in Indonesia, the process is done through high-temperature heating and fermentation. The government has not encouraged the automotive industry to produce vehicles that can use biofuel with a high ethanol content of up to 96 percent. Car engines in Indonesia can only use fuel oil mixed with ethanol up to only 1 percent. If around 96 percent of bioethanol is used as a mixture, the fuel price can be more competitive than Pertamax. Another benefit is that bioethanol is also environmentally friendly [26]. In order to encourage the use of bioethanol in Indonesia, subsidies are needed

Table 1 presents data on the development of the harvested area, production, and productivity of sugarcane during the 2015-2019 period in Indonesia. During that period, the 
harvested area for sugarcane decreased by $-2.50 \%$ /year, from 461.73 thousand ha (2015) to 409.67 thousand ha (2019). Meanwhile, in that period, sugarcane production increased by $3.97 \%$ /year, from 2.29 million tons (2015) to 2.63 million tons (2019). The increase in sugarcane production is because its productivity has increased significantly by $6.35 \% /$ year, from 4.96 tons/ha (2015) to 6.43 tons/ha (2019).

Table 1. Development of sugarcane harvested area, production, and productivity in Indonesia, 20152019 [27].

\begin{tabular}{|c|c|c|c|}
\hline Year & Harvested area (ha) & Production (ton) & Productivity (ton/ha) \\
\hline 2015 & 461,732 & $2,290,116$ & 4.96 \\
\hline 2016 & 417,234 & $2,267,887$ & 5.44 \\
\hline 2017 & 426,012 & $2,438,198$ & 5.72 \\
\hline 2018 & 414,846 & $2,551,026$ & 6.15 \\
\hline 2019 & 409,674 & $2,632,242$ & 6.43 \\
\hline r (\%/year) & -2.50 & 3.97 & 6.35 \\
\hline
\end{tabular}

In East Java Province, in the 2015-2019 period, the harvested area of sugarcane has decreased by $-3.68 \%$ /year, from 206.73 thousand ha (2015) to 18.79 thousand ha (2019). Along with the decline in harvested area, sugarcane production also decreased by $3.93 \%$ /year, from 1.31 million tons (2015) to 1.03 million tons (2019), and its productivity also decreased by 6.34\%/year, from 6.34 tons/ha (2015) to 5.99 tons/ha (2019) (Table 2). East Java contributes around 44 percent to the national sugarcane area and 41 percent to the national sugarcane production.

Table 2. Development of area and production of sugarcane in East Java Province, 2015-2019 [27].

\begin{tabular}{|c|c|c|c|}
\hline Year & Harvested area (ha) & Production (ton) & Productivity (ton/ha) \\
\hline 2015 & 206,729 & $1,310,689$ & 6.34 \\
\hline 2016 & 205,247 & $1,047,414$ & 5.10 \\
\hline 2017 & 203,567 & $1,036,814$ & 5.09 \\
\hline 2018 & 184,858 & $1,065,965$ & 5.77 \\
\hline 2019 & 180,789 & $1,083,600$ & 5.99 \\
\hline r (\%/year) & -3.68 & -3.93 & -0.05 \\
\hline
\end{tabular}

Based on existing sugarcane production data, it can be predicted that the potential of molasses (24\% of sugarcane production) is approximately 260.06 thousand tons in East Java and 631.74 thousand tons in Indonesia. The ratio of molasses to bioethanol is 1:4. Therefore, the potential of bioethanol that can be produced with the existing sugarcane production is around 65.02 thousand tons in East Java and 157.93 thousand tons in Indonesia (Table 3).

Table 3. Sugarcane production, and potential production of molasses and bioethanol in East Java and Indonesia, 2019 [27].

\begin{tabular}{|l|c|c|c|}
\hline \multicolumn{1}{|c|}{ Province } & $\begin{array}{c}\text { Sugarcane production } \\
\text { (tons) }\end{array}$ & $\begin{array}{c}\text { Molasses potential } \\
\text { (tons) }\end{array}$ & $\begin{array}{c}\text { Bioethanol potential } \\
\text { (tons) }\end{array}$ \\
\hline East Java & $1,262,473$ & 302,994 & 75,748 \\
\hline Indonesia & $2,632,242$ & 631,738 & 157,935 \\
\hline
\end{tabular}


Currently, the Indonesian government has made a policy to reduce the use of petroleum, at least by $5-20$ percent by 2025 . With this policy, it is hoped that it will gradually begin to shift the use of BBM by BBN. To implement the use of biofuel, currently, PT Pertamina (Persero) has blended bioethanol with biofuel (BBM). The implementation of bioethanol is carried out in line with the issuance of a Regulation of the Minister of Energy and Mineral Resources concerning the revision of the bioethanol market index price (HIP). The Ministry of Energy and Mineral Resources will increase the bioethanol HIP to Argus $+14 \%$ from the previous Argus $+5 \%$. HIP's determination for bioethanol was previously regulated in the Minister of Energy and Mineral Resources Decree Number 0219/2010 on the HIP for $\mathrm{BBM}$ and BBN mixed into specific fuel types. The regulation states that the bioethanol price formula is based on the Argus published price for ethanol FOB Thailand plus 5\%. With this formula, bioethanol's selling price in the domestic market is only IDR 8,400 per liter or lower than the production cost. Therefore, with the increase to Argus $+14 \%$, bioethanol's selling price is expected to increase by IDR 200 to IDR 300 per liter. To support bioethanol development, the government must make improvements to energy price policies, especially bioethanol, so that it can compete with other fossil energies [14].

By mixing fuel with ethanol, it will be able to increase the octane of fuel. In terms of the potential market for ethanol for fuel blends, it has great potential. This is because the number of vehicles using premium types of fuel is more. However, bioethanol development in Indonesia still seems slow due to inaccurate pricing, which makes entrepreneurs reluctant to develop ethanol. Currently, PTPN X has exported 4,000 cubic meters of alternative energy types of bioethanol to the Philippines. Bioethanol is a product of PTPN X's subsidiary, PT Energi Agro Nusantara (PT Enero).

Despite many potential plants as raw materials for biofuels, however, after a decade since the Indonesian government launched the energy policy, the use of biofuels in Indonesia has not developed well. There are several weaknesses in its development: (1) the program is only applied to specific areas; (2) the synergy of central and regional government policies is not optimal, and (3) the BBN program's target is too high or too ambitious [28].

\subsection{Problems in bioethanol development}

In bioethanol production made from molasses, there are several problems faced, both technical and socio-economic. Technically, the raw material for bioethanol comes from molasses produced by sugar factories. The supply of molasses will depend on the supply of sugarcane sold by sugarcane farmers or farmer groups. KUDs coordinate sugarcane farmers or farmer groups in each sub-district of the research location in Malang Regency, East Java. However, the KUDs have to compete with sugarcane traders or intermediaries. Intermediaries have large capital and can pay cash for the sugarcane sold by farmers and access the sugar factory. KUDs have no bargaining power nor hold sugarcane farmers from not selling their sugarcane to intermediaries because of the need for cash. Meanwhile, payment disbursement for sugarcane from farmers through KUD has to wait for sugar auction hold by the sugar factory for about ten days. This condition makes it difficult for the KUDs to collect sugarcane from farmers. The classic problem faced by farmers is related to the determination of yield by the sugar factory.

Bioethanol processing is currently being carried out at one of the factories owned by PTPN X, namely PT Energi Agro Nusantara (Enero) in East Java. PT Enero has contributed to the field of energy stability for Indonesia, contributing to renewable energy. PT Enero's business focuses on producing 99.5 percent grade of bioethanol fuel as alternative energy for fuel oil using molasses as the primary raw material. Bioethanol production at PT Enero 
reaches 100 kiloliters per day or 30 megaliters per year. According to PTPN X information, the co-generation program that will process sugarcane bagasse into electricity will be implemented in two PTPN X's sugar factories, namely PG Pesantren Baru (Kediri) and PG Gempolkrep (Mojokerto). The two PGs built a bioethanol plant in 2013 and could produce 99 percent fuel-grade ethanol, which is environmentally friendly [30].

To meet raw material needs, the bioethanol factory requires 120,000 tons of molasses per year. Sugarcane drops will be supplied by all PGs owned by PTPN X. So far, molasses have been sold to other industries such as food factories, so the added value is still minimal. PTPN X also collaborates with the third parties to build biofuel power plants from bioethanol waste to meet the electricity needs of PTPN X.

There are still some problems with the development of bioethanol in East Java. These problems are related to technical, socio-economic, and policy aspects. The followings are some problems related to the technical aspect. (a) The stipulated yield level is still low, which does not motivate farmers to increase sugarcane farming. (b) There is competition for agricultural land use, in which farmers tend to plant their land with crops that are most profitable to farmers. (c) The sugarcane farming system is not yet optimal, with the productivity level of sugarcane produced by farmers ranges from 80 to 100 tons/ha. (d) The processing of molasses into bioethanol is still limited. (e) The real production capacity of bioethanol produced is still below the installed production capacity, given the limited bioethanol market.

The problems faced related to the socio-economic aspects of sugarcane farming are (a) limited capital owned by farmers; (b) uneven distribution of superior seedlings; (c) high farming costs; (d) limited availability of labor in several producing centers accompanied by increasing labor wages; (e) fluctuating price of auctioned sugar, ranging from IDR 8,000 to IDR $8,500 / \mathrm{kg}$ in the last two years, and the price of molasses is IDR $3,000 / \mathrm{kg}$; (f) imbalanced partnerships between sugarcane farmers and PGs, especially in the marketing of products, in terms of manner and benefit; and $(\mathrm{g})$ limited sugarcane marketing, only to the nearest PG. Meanwhile, the problems in processing sugarcane into bioethanol are (a) fluctuating sugar prices generate less incentive in developing sugarcane farming; (b) the bioethanol produced has not been consistently absorbed by the domestic industry; (c) the policy for bioethanol development has not been synchronized with energy policies in general, especially in mixing with BBM; (d) the cost of producing bioethanol is quite high, namely IDR 7,000/liter, while in Thailand and India it is only IDR 5,000/liter; and (e) competition in the use of molasses.

Furthermore, constraints from the aspect of sugarcane farming development policies can include (a) institutional sources of capital which are often difficult to access by small farmers, while the KKPE credit scheme is also not widely used by farmers; (b) complete supply and distributor institutions in rural areas are often limited; (c) the implementation of sugarcane farming development policies has not been well realized.

In general, bioethanol development efforts still have good opportunities both from technical and socio-economic aspects. The potential for molasses in East Java is quite large. Assuming that the national production of sugarcane in 2014 was 33.5 million tons, then the molasses produced could reach around 502,500 tons per year or equivalent to $125,625 \mathrm{~kL}$ of bioethanol. The technology for processing molasses into bioethanol is available in the country, and currently, among others, it has been implemented by PT Enero. Furthermore, the waste from bioethanol processing can be used as potential biogas to generate electricity for industrial needs. For example, PT Enero can produce 1,125 m3 of biogas waste, which can be used to produce up to 2 megawatts of electrical energy. This is a positive effort also to support energy security. 
Meanwhile, bioethanol development opportunities from a socio-economic aspect include (a) the potential of molasses in East Java is quite large, with prices ranging from IDR 1,000 to IDR $1,700 / \mathrm{kg}$, and the proportion of molasses costs to production costs is $60 \%$; (b) waste from bioethanol can be used as potential biogas to generate electricity for industry; (c) demand for bioethanol is still quite high, for example, special bioethanol demand in Surabaya, East Java, can reach 15 million liters per day; (d) government policy in the long term for bioethanol development is quite supportive and still needs to be more synchronized with energy policy in general.

\subsection{Economic analysis of molasses development and its development into bioethanol}

Sugarcane farming activities in East Java are generally carried out in paddy fields and dry land with a monoculture system. A variety that is mostly cultivated by sugarcane farmers is Bulu Lawang, with a productivity level of 80-100 tons/ha of sugarcane. Farmers usually plant it at the beginning of the rainy season. In the structure of sugarcane farming costs, the land rental cost contributes the highest proportion to the total farming costs. The cost of renting dry land ranges from IDR 15 million to IDR 20 million/ha/year.

For processing sugarcane into bioethanol, some information obtained shows that (a) the price of bioethanol products is around IDR 7,800 per liter; (b) the cost of producing bioethanol from molasses is IDR 5,300/liter, and (c) BEP, the price of bioethanol is around IDR 7,000 per liter. Thus, the business of processing sugar cane into bioethanol is still feasible (profitable) (Table 4).

Table 4. Business feasibility analysis of bioethanol from sugarcane drops at PT Enero East Java, 2016 (per liter of bioethanol yield) [29].

\begin{tabular}{|l|c|}
\hline \multicolumn{1}{|c|}{ Description } & Value \\
\hline 1. Price of raw material for sugarcane drops (IDR/liter) & 1,700 \\
2. Production cost (IDR/liter) & 5,300 \\
3. Price of BEP bioethanol (IDR/liter) & 7,000 \\
4. The selling price of bioethanol in the market (max, IDR/liter) & 7,800 \\
\hline
\end{tabular}

Note: USD 1 = IDR 13,000.

For the development of bioethanol production in East Java, there are several factors supporting the development of sugarcane, both technical and socio-economic aspects. The policies related to technical aspects include (a) increasing productivity and yield of sugarcane; (b) expansion of planting areas; (c) institutional development of farmer groups and support related to sugarcane cultivation: availability of seedlings, capital, and the market for sugarcane. Efforts can be made to increase sugarcane productivity because there is still a productivity gap between genetic potential and productivity at the farmer level. Efforts to increase productivity can be pursued using superior quality seedlings, using fertilizers as recommended, and supporting infrastructure to support cultivation and marketing.

The development support from the socio-economic aspect is: (a) Increasing the role of extension, namely to support the achievement of sugarcane development programs; (b) Coordination of related agencies in order to accelerate the development of sugarcane as an alternative energy raw material; (c) conducive policies, namely the creation of a business climate that supports the development of sugarcane agribusiness and bioethanol prices; and (d) Increasing the human resources of farmers, through empowerment and capacity building in both on farm and off farm activities through various empowerment media. 
Efforts to develop bioethanol made from molasses (molasses) have a great opportunity to continue to be improved. At PTPN X, If the total production of sugarcane is 6.1 million tons, it will produce 400 tons of molasses per day or about 96,000 tons of molasses per year. In several countries, such as India and Brazil, the profits of sugar factories actually come mostly from the sale of bioethanol. Therefore, efforts to support PTPN to integrate sugar factories with other products, such as bioethanol, biogas (waste from the bio-ethanol process), $\mathrm{CO}_{2}$, and liquid fertilizers are to be further improved.

\section{Conclusions and recommendations}

Sugarcane is one of the raw materials for bioethanol. The development of bioethanol using sugarcane as a raw material in Indonesia is quite potential because Indonesia is a considerably large sugarcane producer. Based on existing sugarcane production data, it is predicted that the potential of molasses (24\% of sugarcane production) is approximately 302.99 thousand tons in East Java and 631.74 thousand tons in Indonesia.

Technical aspects and problems in the development of sugarcane and molasses as raw materials for bioethanol at the research location of East Java Province include (a) low sugar yields, less motivation for farmers to increase sugarcane farming; (b) the distribution of superior seedlings is often uneven; (c) there is competition for farming land use; (d) processing of molasses into bioethanol is still limited; and (e) the real bioethanol production capacity is still below the installed capacity. the socio-economic problems of processing molasses into bioethanol are (a) fluctuating sugar prices; (b) bioethanol produced by industry has not been absorbed optimally; (c) the bioethanol development policy is not yet synchronized with the energy policy in general; (d) the cost of producing bioethanol is still quite high; (e) competition in the use of molasses in meeting export demand and the domestic bioethanol industry.

Efforts to develop sugarcane as a producer of molasses as raw material for bioethanol need to be continuously carried out. This can be achieved, among others, through (a) increasing the role of extension services in supporting sugarcane development programs; (b) coordination of related agencies in order to accelerate the development of sugarcane as an alternative energy raw material; (c) conducive policies, namely the creation of a business climate that supports the development of sugarcane agribusiness; (d) increasing the human resources of sugarcane farmers.

Currently, there are limited producers of bioethanol made from molasses. Meanwhile, the potential for molasses from sugar factories is currently quite large and has not been fully utilized. Supporting policies for the development of molasses processing into bioethanol include (a) capital support for bioethanol producers made from molasses; and (b) the need for optimal government involvement in ensuring the bioethanol market, as well as synergies with other energy policies.

\section{References}

1. D. Khatiwada, S.Silveira. J. Energy, 119 (2016)

2. M. O. S. Dias, R. M. Filho, P. E. Mantelatto, O. Cavalett, C. E. V. Rossell, A. Bonom, L.V. Leal, Environ. Dev. 15, 35 (2015)

3. M. Kohler, SAEF Working Paper No. 2016/01/08 (2016)

4. S.C. Rabelo, H.Carrere, R.M. Filho, A.C.Costa. J. Bioresour. Technol. 102, 17 (2011) 
5. M. L. Lopes, S. C. L. Paulillo, A. Godoy, R. A. Cherubin, M.S Lorenzi, F.H.C. Giometti, C. D. Bernardino, H. B. A. Neto, H. V. Amorim, Brazilian J Microbiol. 47S, 64 (2016)

6. D.S.Andrade, F.Z. Gavilanes, H.R. Silva, G.H.L. Castro, T.S. Telles. Sustainable bioenergy production (Chapter 19) Recent Developments in Bioenergy Research (Elsevier B.V., 2020)

7. S.H. Gheewala, B. Damen, X Shi. J. WIREs Climate Change 4, 6 (2013)

8. J. Tomei, Biomass Bioenerg. 82, 94 (2015)

9. L. Bhatia, S. Johri, R. Ahmad. J. AMB Express 2, 65 (2012)

10. M.H. Jayed, H. H.Masjuki, M.A.Kalam, T.M.I.Mahlia, M. Husnawan, A.M. Liaquat. J. Renew. Sust. Energ. Rev. 15, 1 (2011)

11. D. Khatiwada, B. K. Venkata, S.Silveira, F. X. Johnson, Appl. Energ. 164, 756 (2016)

12. M. Arshad, M. Abbas, M. Iqbal, Environ. Technol. Innov. J. 14, 2352 (2019)

13. T. Silalertruksaa, S. H. Gheewalaa, Energy Procedia 9, 35 (2011)

14. A. Farooq, A. Bangviwat, S. H. Gheewala, J. Sustain. Energy Environ. 11, 49 (2020)

15. Indonesian National Defense Institute (Lemhanas) RI, J. Kajian Lemhanas RI, 14 (2014)

16. J.Popp, Z.Lakner, M.H.Rákos, M.Fári. J. Renew. Sust Energ. Rev. 32 (2014)

17. A. Bušić, N. Marđetko, S. Kundas, G. Morzak, H. Belskaya, M. I. Šantek, D. Komes, S. Novak, B. Šantek. J. Food Technol. Biotechnol. 56, 3 (2018)

18. A. Bogdanski, O. Dubois, C. Jamieson, R. Krell, Making Integrated Energi Food Sytem Work for People and Climate: An Overview (Food and Agriculture of the United Nations, Rome, 2010)

19. A. Er, Asian Soc. Sci. 7, 2 (2011)

20. Z. Zhang, Marcin, Sustainability 12, 1368 (2020)

21. J. Goldemberg, Sugarcane Ethanol: Strategies to a Successful Program in Brazil (Chapter 2) Advanced Biofuels and Bioproducts (Springer, New York, 2013)

22. F. Hartley, D.V. Seventer, E. Tostão, C. Arndt, Dev. Southern Africa 36, 233 (2019)

23. E. O. Ziety, J. Gołaszewski, M. Krzykowski , J. Zięty, H. V. Klink, IOP Conf. Ser.s: Earth Environ. Sci. 214 (2019).

24. E. Hermiati, D. Mangunwidjaja, T. C. Sunarti, O. Suparno, B. Prasetya, J. Penelit. Pengemb. Pertan. 29, 4 (2010)

25. National Energy Council, Bahan Rapat Integrasi BBN (National Energy Council, Jakarta, 2014)

26. M. Hassan, M. A. Kalam. J. Procedia Eng. 56 (2013)

27. Directorate General of Plantation, Statistics on Sugar Cane and Oil Palm Plantations (Directorate General of Plantation, Jakarta, 2015)

28. D.A.P.E. Wishanti. J. Procedia Environ. Sci. 28 (2015)

29. PT Enero, Informasi mengenai Industri Pengolahan Bioetanol dari Tetes Tebu (PT Enero, Mojokerto, 2015)

30. N.P. Patil, V.S. Patil. Indian J. Nat. Prod. Resour (IJNPR) 3,1 (2017)

31. A.F. Tayab, M. M.Z. Khan, S. M. R. Islam, M.S. E. Sharif. Int. J. Pharm. Chem. 5, 4 (2019)

32. F. Hartley, D. V. Seventer, E. Ostao, C. Amdt. J. Development Southern Africa 36, 2 (2019). 